This item was submitted to Loughborough's Research Repository by the author.

Items in Figshare are protected by copyright, with all rights reserved, unless otherwise indicated.

\title{
Foreign competition and innovation: The mediating role of imitation
}

PLEASE CITE THE PUBLISHED VERSION

https://doi.org/10.1111/1467-8551.12236

PUBLISHER

Wiley @ British Academy of Management

VERSION

AM (Accepted Manuscript)

PUBLISHER STATEMENT

This work is made available according to the conditions of the Creative Commons Attribution-NonCommercialNoDerivatives 4.0 International (CC BY-NC-ND 4.0) licence. Full details of this licence are available at: https://creativecommons.org/licenses/by-nc-nd/4.0/

\section{LICENCE}

CC BY-NC-ND 4.0

\section{REPOSITORY RECORD}

Xia, Tianjiao, and Xiaohui Liu. 2017. "Foreign Competition and Innovation: The Mediating Role of Imitation". Loughborough University. https://hdl.handle.net/2134/25000. 


\title{
Foreign Competition and Innovation: The Mediating Role of Imitation
}

\section{Tianjiao Xia}

School of Business and Economics, Loughborough University

Leicestershire LE11 3TU, UK

Email: T.Xia@lboro.ac.uk

\author{
Xiaohui Liu ${ }^{1}$ \\ a. School of Business and Economics, Loughborough University \\ Leicestershire LE11 3TU, UK \\ Tel: 44(0)1509-223349 \\ Email: X.Liu2@lboro.ac.uk
}

Acknowledgements

We gratefully acknowledge Associate Editor, Professor Douglas Cumming and three anonymous reviewers for their constructive and insightful comments.

${ }^{1}$ Corresponding author 


\title{
Foreign Competition and Innovation: The Mediating Role of Imitation
}

\begin{abstract}
This study examines the extent to which foreign competition affects the innovation performance of domestic firms through imitation, given firms’ absorptive capacity. In analyzing longitudinal firm-level data from the U.K., we find a mediating effect of imitation on the relationship between foreign competition and local firms' innovation performance, and an inverted U-shaped relationship between imitation and the innovation performance of local firms. Our findings further reveal that absorptive capacity moderates the mediating effect of imitation, diminishing innovation gains at moderate levels of imitation and mitigating the diminishing innovation performance at high levels of imitation.
\end{abstract}

Keywords: foreign competition; imitation; innovation; absorptive capacity 


\section{Foreign Competition and Innovation: The Mediating Role of Imitation}

\section{Introduction}

It is well established that competition breeds innovation (Aghion et al., 2005). Without competition, firms have less incentive to keep trying out new ideas and finding what works best amongst these ideas. However, competition may also induce imitation and can impact innovation indirectly channelled through imitation (Aghion et al., 2001). Imitation is considered a 'smart' strategy (Lieberman and Asada, 2006; Shenkar, 2010) as imitators do not have to take on the same level of risk and uncertainty as the initial innovators. On the production side, they can copy, emulate or reverse engineer the product design or service delivery of an innovator. On the market side, the imitators can learn from the innovators about consumers' appetite for a particular product or service (Johnson et al., 2008). Recent studies have shown that imitators can help generate further innovation, because they may have valuable information or ideas not available to the original innovator (Bessen and Maskin, 2009; Cappelli et al., 2014).

Despite its innovation-enhancing effect, imitation may also discourage a firm's incentive to innovate. Although the rewards of imitation are not as high as those of innovation, picking lower hanging fruit is a safer strategy than innovation for firms with a priority to survive rather than thrive (Hurmelinna-Laukkanen and Olander 2014; Ross and Sharapov, 2015). Equally, at a higher level of competition, an increase in competition is more likely to reduce the rate of innovation, as the followers' rewards for catching up with the leader via innovation may fall due to a decreased market share (Schumpeter, 1950; Li and Vanhaverbeke, 2009). This 
suggests the possibility of a non-linear feedback effect of imitation on innovation at different levels of competition. However, existing research has overemphasized the direct links between competition, imitation and innovation separately (Damanpour, 2010; Driffield et al., 2014; Fu, 2012). Such a focus takes no account of the indirect effect of imitation and may lead to an overestimation and oversimplification of the influence of competition on innovation. We have a limited understanding of the overall relationships among these factors, and the underlying mechanisms through which competition affects innovation.

Moreover, imitation and innovation involve learning that is determined by a firm's absorptive capacity, defined as the ability to acquire, assimilate and exploit new external knowledge (Cohen and Levinthal, 1990). Hurmelinna-Laukkanen and Olander (2014), for instance, find an important indirect effect of rivals’ ACAP on firms' innovativeness through changes in the strength of their appropriability regimes based on a study of 155 Finnish firms. However, the interrelationship between imitation, innovation and ACAP remains underexplored in prior studies. We know little about the conditions under which imitation can benefit innovation. Addressing this question may offer new insights into the role of imitation in innovation, as existing studies overly stress the negative effect of imitation or its limited novelty value, but neglect the fact that most original thoughts are actually built on the strength of existing ideas (Hunter, 2013).

The complex relationship between competition, imitation and innovation has neither been looked at closely nor systematically, with little fine-grained analysis to account for the heterogeneity in the source of competition, i.e. foreign competition. The rapid pace of globalization in the past three decades leads to increasingly intensified competition from foreign rivals at home (D’ Aveni, 1994). Foreign 
competition brings in a great variety of external knowledge to the domestic economy. The institutional contexts that shape the business models and innovation activities of foreign rivals can vary substantially from domestic businesses, which may provide them with unique advantages (Jacobides and Winter, 2012; Li and Vanhaverbeke, 2009). This raises the bar in the battle for survival by local firms, making their imitation and innovation no longer a domestically isolated process. Thus, increasing foreign competition not only represents new learning opportunities for local firms, but also raises an important research question concerning to what extent they are able to reap innovation related benefits from imitating foreign rivals. Empirically, while imitation is considered an important stepping stone for innovation in previous studies (Zhou, 2006; Kale and Little, 2007), its mediating role has not yet been examined. There is a missing mechanism between foreign competition and innovation as imitation is considered an important integral part of the innovation process (Lee and Lim, 2001). Thus, it is theoretically and empirically important to examine the overall relationship between foreign competition, imitation and innovation by delineating whether imitation serves as an explanatory mechanism through which foreign competition affects innovation indirectly. The potential mediating role of imitation may be salient in the indirect relationship between foreign competition and innovation.

Drawing on an integrated theoretical framework of imitation based on information and competitive rivalry, and organizational learning theory, we propose a positive impact of foreign competition on imitation which in turn has an inverted Ushaped relationship with the innovation performance of local firms. Moreover, we argue that ACAP moderates the proposed inverted U-shaped relationship between imitation and innovation performance by reducing the importance of imitation to 
innovation performance at a moderate level of imitation and mitigating the diminishing effect of imitation at a high level of imitation.

To address the research gaps identified above, we make a number of contributions. First, our study complements information-based and competitive rivalry-based imitation theories by exploring the mediating effect of imitation on the foreign competition- innovation relationship. Specifically, we are able to articulate the conditions under which imitation is beneficial or detrimental to local firms’ innovation performance in the context of foreign competition. Our finding of an inverted U-shaped relationship between imitation and innovation also sheds new light on the tension between imitation and innovation. Second, our study enriches and refines organizational learning theory by offering a new insight on the conditions and the extent to which local firms can reap innovation-related benefits through learning by imitating their foreign counterparts' knowledge and/or business ideas.

\section{Theory and hypotheses}

\section{Theoretical background}

There are two main bodies of literature that attempt to explain firms' imitative behavior in the face of foreign competition and these are the information-based and competitive rivalry-based perspectives (Anand et al., 2009; Lieberman and Asaba, 2006; Semadeni and Anderson, 2010). Each explains firms' imitation activities at a different level of information asymmetry characterized by the stage of foreign competition. Deeply rooted in the fields of sociology, psychology and economics, information-based imitation emphasizes the fact that in uncertain industry environments, such as foreign competition with high levels of asymmetric information, firms are more likely to follow competitors who possess superior 
innovation capabilities (Lieberman and Asaba, 2006; Bikhchandani et al., 1992). Foreign firms entering the local market with new products and/or services may be perceived as possessing superior innovation capabilities by local firms (Bikhchandani et al., 1992). Such superior innovation capabilities may lie in foreign firms’ unique interpretations of the host market conditions, which are mainly shaped by the variations in their cognition and home country institutional contexts. Their competitiveness derived from these capabilities is less likely to be subject to the liability of foreignness (Zaheer, 1995; Wu and Salomon, 2016), which is usually overcome by leveraging their ownership-based advantages and/or acquiring or collaborating with local firms in downstream activities (Zaheer, 1995; Ramamurti and Singh, 2009). In fact, research shows that the liability of foreignness diminishes as foreign firms gain more host-country specific experience, and even disappears after some time (Zaheer and Mosakowski, 1997).

As the competitive relationship between foreign and local firms becomes more established, the level of information asymmetry declines and firms are more likely to possess similar levels of knowledge about the domestic market (Baum and Korn, 1996; Gimento and Chen, 1998). Given low information asymmetry, the competitive rivalry-based imitation explains the relationship between competition, imitation and innovation from the aspects of competitive rivalry and risk reduction (Peteraf, 1993; Baum and Haveman, 1997; Head et al., 2002). Increasing foreign competition stimulates rivalry-based imitation and such imitation allows local firms to maintain their relative position and/or to neutralize the aggressive actions of foreign rivals and/or reduce risk. When competitors adopt homogeneous strategies, it is less likely that any firms will succeed or fail relative to others. Such herd behavior discourages 
any individual firm from acting aggressively in an effort to gain competitive advantage (Hirshleifer and Teoh, 2003; Lieberman and Asaba, 2006).

It is well documented in prior studies that competition may directly lead to innovation regardless of the existence of imitation (Kafourous and Buckley, 2008; Li and Vanhaverbeke, 2009), as innovation can be based on a firm's internal ideas and/or knowledge, and use internal paths to market (Chesborough, 2003; Cassiman and Veugelers, 2002). This implies that imitation does not necessarily strengthen or weaken the relationship between foreign competition and innovation. Rather, imitation may enable firms to move up their innovation ladder by acting as a mechanism through which firms learn about creative ideas, best practice and compelling business models from their rivals (Park and Bae, 2004; Zhou, 2006). Thus, we incorporate an organizational learning perspective into the main theories on the motivation for imitation at different levels of foreign competition to capture the impact of imitative learning and ACAP on local firms’ innovation performance. Organizational learning theory highlights the importance of accessing, acquiring and utilizing external knowledge for innovation (Levitt and March, 1988; Simon, 1969). Organizations with superior learning capabilities are able to benefit from their foreign rivals as the presence of these rivals is associated with an increasing variety of knowledge sources which motivate local firms to learn new ways of improving their competitive position (Clercq et al., 2012; Derfus et al., 2008). In this regard, learning through imitation in the face of foreign competition may spur innovation and contribute to innovation performance. 


\section{Hypotheses}

\section{Foreign competition and imitation}

Foreign competition can affect imitation in a number of ways. First, being new to the local context, and having different firm-specific capabilities and business models, foreign firms represent a source of new knowledge and thus their presence in the local market provides opportunities for domestic firms to learn and/or imitate (Fu, 2012; Jacobides and Winter, 2012). Through imitation, domestic firms can compete with foreign firms by combining their internal knowledge with a variety of knowledge from international sources (Chang and $\mathrm{Xu}, 2008)$.

In addition, imitation provides cost advantages and represents a risk reduction mechanism as it enables firms to avoid costly investment in $R \& D$, and so reduces the risk of failure (Semadeni and Anderson, 2010; Ross and Sharapov, 2015). Being late movers, imitators can see which ideas have been accepted by the market. As foreign competition becomes intensified, the profit margins will erode due to increased industry capacity (Barringer and Ireland, 2008). This makes imitation at low cost a more economic strategy for domestic firms to pursue, as inventors may not reap enough profits to cover their innovation costs (Lieberman and Asada, 2006; Shenkar, 2010).

On the other hand, foreign competition can increase the likelihood of failure for those that do not follow, even in industries where strong rivalry is maintained. The theoretical explanation for this is derived from early studies on competition and collusion (Axelrod, 1984). This body of literature suggests that firms within the same group tend to adopt similar behavior to constrain competition and maintain collusion. Deviant behavior is punished as it reduces the ability of oligopolists to coordinate their actions tacitly and leads to lower average industry profitability (Derfus et al., 
2008). One example for this is the relationship between Cannon, Nikon and Kodak, the world leaders in the high-end digital single-lens reflex (DSLR) camera market. The three companies have followed each other's innovation footpaths since early 2007 (Williams, 2007; Ottke, 2015). This gave these firms the opportunity to build their offerings based on the market reaction to each other's innovation. In doing so, they copied each other's ideas and very often came up with cheaper or better solutions. Once an enhanced version of the DSLR camera with significant improvements in functional characteristics, such as technical specifications, components and materials, incorporated software and so on, was launched by the counterparts, this imitation cycle started again. As a result, they were on par with each other in terms of overall market share and emerged with almost identical product lines (BusinessWire, 2014). The competitive positions of these companies were mutually strengthened by their ongoing battles with each other in multiple arenas, which enabled them to effectively drive many foreign rivals out of the global market. Our discussion suggests that foreign competition may affect local firms' imitation (Figure 1).

H 1a: Foreign competition has a positive effect on the imitative behavior of local firms.

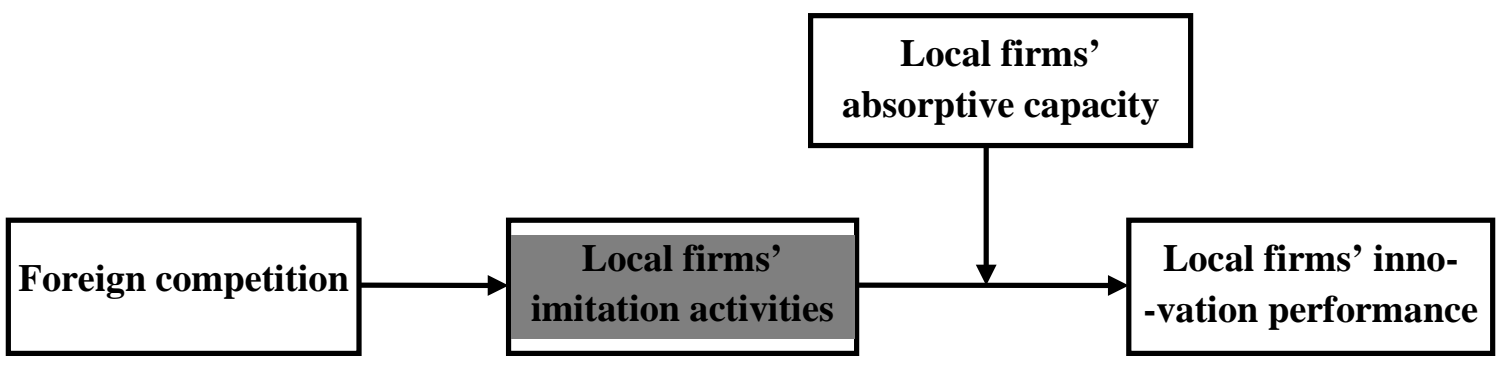

Figure 1. A conditional mediation model 


\section{Imitation and innovation}

Imitation and innovation are considered to be two mutually exclusive activities in prior literature (Abrahamson, 1996; Lieberman and Asaba, 2006; Semandeni and Anderson, 2010). There is a clear trade-off between these two types of activities. Innovation generates new knowledge and advances progressiveness, which enables firms to effectively capture market changes with performance rewards in highly uncertain environments. However, too much innovation can threaten organizational legitimacy (Deephouse, 1999) and may imperil firm performance (March, 1991; Levinthal and March, 1993). By contrast, imitation reinforces rationality by defusing rivalry competition and reducing risks and costs. In turn, an excessive focus on imitation may exhaust firms’ opportunities to keep up with changing market conditions. Specifically, imitative behavior can be dysfunctional, and compound the collective risk of firms in an industry by reducing variety when environmental uncertainty is high (Lieberman and Asaba, 2006). Thus, firms maintaining a balance between these two activities can achieve superior performance by offering products that appear attractive and in step with the market (Abrahamson, 1996).

While these studies mainly focus on examining the performance effect of each construct, the potential link between imitation and innovation has yet to be thoroughly explored (Kim, 1997; Lee and Lim, 2001; Ross and Sharapov, 2015). Innovation can be based not only on new knowledge, such as a ground-breaking scientific discovery, but also on a new application of existing knowledge which is triggered by imitation (Cohen and Levinthal, 1990). It is widely observed that most innovations result from borrowing ideas from others rather than internal invention (Myers and Marquis, 1969; von Hippel, 1988). Imitation also allows firms to borrow analogical solutions in one field to solve intricate problems in another field, which is accomplished by 
interpreting the same knowledge in a different manner (Zahra and George, 2002; Enkel and Gossmann, 2010).

In addition, variations in firms’ prior knowledge bases suggest that the imitators may have valuable ideas not available to the original discoverer. This may help enhance the overall pace of innovation (Bessen and Maskin, 2009). Imitators might improve the existing innovation, building on the experience of the innovators. Moreover, the existence of a sufficient degree of cognitive distance between a potential imitator and the innovator is more likely to enhance opportunities for novel combinations of acquired knowledge and a firm's existing knowledge (Nooteboom, 1999; Nooteboom et al., 2007). Even in the case where imitators attempt to ride the coattails of the innovator by copying all aspects of an innovation (Abrahamson, 1996), the conversion from imitation to innovation can simply be achieved by novel interpretation of the same knowledge (Zahra and George, 2002).

The above discussed rationale for a linear positive relationship between imitation and innovation, based on knowledge accumulation, overemphasizes the potential benefits of imitation, but understates its costs, with a static view of the pace of the growing influence of each factor (Bessen and Maskin, 2009). We argue that the costs of imitation after a certain point may escalate faster than its potential benefits to innovation. There are several rationales based on increasing costs at higher levels of imitation which support the existence of a curvilinear (inverted U-shaped) relationship.

Our first rationale for the curvilinear relationship is that the costs of searching for new ideas and/or knowledge from external sources are growing substantially. Local firms have to invest additional resources to expand the scope of their search once existing foreign knowledge sources are exhausted (Cohen and Levinthal, 1990; 
Roberts, 2015). Increased levels of imitation make it harder for local firms to look for foreign firms with sufficient cognitive distance to provide novelty, as the more one knows, the further away one has to look for novelty (Nooteboom et al., 2007). As a result, resource investments may become less efficient, because the resource commitments necessary to search for new knowledge increase as the scope of the search broadens, and local firms have to go through an increasingly wide search for novel knowledge.

The second rationale for the curvilinear relationship is that the conversion from imitation to innovation is increasingly costly. As local firms' levels of imitation intensify, they are more likely to regularly encounter external knowledge sources with which they share little common language (technical and/or contextual) (CasadesusMasanell and Zhu, 2013). However, an extensive focus on imitation, with a low level of investment in R\&D into emerging market opportunities, limits the capability of local firms to interpret the complex evolution of innovation in the market and to identify external knowledge that is beneficial for exploiting market imperfections. Existing studies show that firms excessively engaged in imitation tend to subcontract most of their R\&D tasks, instead of performing complex R\&D tasks in house or via R\&D cooperation (Veugelers and Cassiman, 1999). Nevertheless, both in-house and cooperative R\&D is an important mode of knowledge acquisition for firms’ innovation activities (Cohen and Levinthal, 1990; Cassiman and Veugelers, 2002; Enkel et al., 2009), and enhances their capacity to integrate new concepts as well as their adaptability to market changes (Freel, 2000). Thus, the lack of capability to fully comprehend and appropriately value increasingly dissimilar external knowledge at higher levels of imitation contributes to distortion and loss of information when local firms attempt to decode, interpret and ultimately apply the knowledge acquired from 
foreign rivals in their own context, leading to missed opportunities (Zahra and George, 2002; Schramm, 1961).

Noteworthy is that for local firms, the ultimate goal is to effectively imitate the new ideas, business models and best practice of foreign rivals rather than to replicate their existing knowledge/technologies, as it is likely that the technologies may become obsolete rapidly (Casadesus-Masanell and Zhu, 2013). Foreign firms may also continuously make incremental improvements in their existing new products or technologies to keep ahead of the innovation race (Xia et al., 2014). This makes fast imitation difficult to achieve (Un, 2011). Equally, local firms may deliberately avoid imitating an untested foreign innovation to limit its downside risk, while keeping pace with the fast-moving domestic marketplace. Moreover, imitators may not be able to imitate efficiently due to various obstacles used by foreign firms to protect their innovation, such as patenting, which need to be bypassed and may compel local firms to innovate (Dasgupta and Stiglitz, 1980; Lorenz et al., 2015). The existence of causal ambiguity further suggests that business models and/or technological competences may be rooted in foreign firms' unique organizational and home country environments, which makes them more complex, highly firm-specific and difficult to effectively duplicate elsewhere, specifically in a new context (Reed and Defillippi, 1990; Strang and Still, 2006). This suggests that the impact of imitation on innovation may not be proportionally related to the extent of imitation due to intangible barriers to imitation (Barney, 1991).

The above discussion implies that up to a certain threshold, increasing imitation is more likely to enhance the innovation performance of local firms (Figure 1). However, beyond this threshold, the cost of imitation overrides its potential 
benefits to local firms' innovation, leading to diminishing returns on their innovation performance. Thus, we hypothesize that:

H1b: Local firms’ imitation resulting from foreign competition has a curvilinear (inverted U-shaped) effect on their innovation performance, with innovation performance increasing at low levels of imitation and decreasing at high levels of imitation.

\section{The mediating role of imitation}

Hypotheses 1a and 1b suggest that imitation will mediate the relationship between foreign competition and the innovation performance of local firms. The impact of foreign competition on firm innovation performance has been well studied in the strategy and innovation literature (Aghion et al., 2008; Tang, 2006). An enhanced innovation performance could also result from imitation, in particular through novel exploration of the commercialization potential of competitors' ideas or knowledge (Zahra and George, 2002; Enkel and Gossmann, 2010). For instance, the MP3 technology was invented by the German company Fraunhofer-Gesellschaft and commercialized by companies such as UPMAN and Sony. However, it was Apple who unveiled its quiescent meaning via the creation of the iPod, allowing people to produce their own personal music through an entire system. The iPod incorporates the iTune application, the iTune store and the business model for selling music that let people discover, taste, buy, store, organize and listen to music in a seamless experience.

Thus, given that foreign competition affects local firms' imitation activities, which in turn influences their innovation performance (Figure 1), we propose that the 
innovation-enhancing role of foreign competition is path dependent, and imitation represents an intermediate channel that accounts for the ultimate impact of foreign competition on local firms’ innovation performance.

H1c: The impact of foreign competition on local firms' innovation performance is mediated by the local firms' imitation.

The interaction effect of ACAP

Imitation is an important form of learning that is affected by a firm's ability to acquire, assimilate and exploit new external knowledge (Argote, 1999; Cohen and Levinthal, 1990). Imitation in this context is not only the simple reproduction of existing knowledge outside a firm’s boundary that characterizes imitative learning, but also involves knowledge creation accomplished by creative learning. The path dependent and cumulative nature of the learning process suggests that both types of learning are equally important to the outcome of firms' imitation. The extent to which duplicative imitation is transformed into the creative imitation that characterizes innovation depends crucially on firms’ ACAP, which determines their ability to use external knowledge (Cappelli et al., 2014; Escribano et al., 2009). Strong ACAP facilitates successful exploitation of externally acquired knowledge as it enables firms to develop and refine the routines that help combine existing knowledge, and the newly-acquired and assimilated knowledge, via imitation to create new products (Penner-Hahn and Shaver, 2005).

Firms with greater ACAP are more likely to possess rich pre-existing knowledge structures that can help to develop and enhance their knowledge diversity and skill set. However, this can also make it harder for these firms to dislodge 
themselves from the core rigidities of their existing knowledge and expertise. There is less chance that incoming information or knowledge acquired through imitation can be related to something different from what is already known by firms with strong ACAP (Cohen and Bacdayan, 1994; Jansen et al., 2005). Their cognitive processes are mainly inspired by accumulated experience in certain specific areas, which constrains their capability to generate and further develop new ideas beyond their existing knowledge domain (Cohen and Levinthal, 1990, Nooteboom, 1999). This, however, limits the scope and level of novelty so that external knowledge can be exploited and converted into new products or services, especially when knowledge acquired through imitation has less similarity to firms’ existing knowledge. By contrast, for firms with weak ACAP, the influence of prior experience on their cognitive processes is less because of their limited ability to make sense of prior knowledge (Fosfuri and Tribó, 2008; Szulanski, 1996). This restricts their ability to pursue duplicative imitation. Thus, they are more likely to search and discover new knowledge outside their existing knowledge domain which can be used to relate to incoming information, though in a less efficient manner than those with stronger ACAP. This search process dislodges these firms from their current practices and increases the scope for these firms to make novel associations and linkages, which is of pivotal importance to their innovation performance; for example, a company can imitate small chunks and then adapt subsequently to reach a better configuration of its practices and knowledge base (Shenkar, 2010). Thus, at moderate levels of imitation, an increase in firms' ACAP leads to a decrease in the innovation performanceenhancing effect of imitation.

As we argued in hypothesis 1b, over reliance on imitation exhausts firms’ innovation performance due to the absence of sufficient internal capability to perform 
R\&D related tasks. However, the possession of strong ACAP may help firms mitigate the diminishing innovation-related returns from excessive imitation activities, as it allows the firms to effectively integrate knowledge learnt through imitation with their existing knowledge to exploit product and market imperfections. Moreover, firms that excessively engage in imitation are exposed to a variety of external knowledge. They need to possess great ACAP to track and evaluate the latest developments outside their boundaries (Cohen and Levinthal, 1989) so that they can selectively exploit the external knowledge that is valuable to their innovation process only. Thus, at higher levels of imitation, an increase in ACAP leads to a decrease in the innovation performance-diminishing effect of imitation (Figure 1). We propose that:

H2: The greater ACAP a local firm has, the less pronounced the inverted Ushaped relationship will be between a local firm's imitation and its innovation performance.

\section{Data and methods}

\section{Data and sample}

We focus on a sample of UK firms, given that the U.K. is regarded as an open economy and has attracted a substantial amount of inward foreign direct investment which affects the imitation and/or innovation activities of local firms (Fu, 2012) The data for our analysis was drawn from the U.K. Community Innovation Survey (CIS) 4-7, which covers U.K. firms' innovation activity for the period 2002-2010, matched with foreign competition information taken from the U.K. Annual Business Survey (ABS) database for the same period. The CIS is an enterprise-based survey administered bi-annually with the sample drawn from the U.K. Office for National 
Statistics Inter-departmental Business Register (IDBR). This allowed us to build a panel dataset with four observation spells based on each round of the survey. CIS4-7 focuses on businesses with 10 or more employees in Sections B-N of the Standard Industrial Classification (SIC) (2007), including manufacturing, construction and marketed services across all U.K. regions. CIS 4-7 respondents were matched on the basis of their 'Ruref' number and thus we were ultimately able to match 314 businesses with 1,256 complete observations. Detailed information on the industry classifications of the sample firms and the matching methods is presented in Appendix 1.

\section{Measures}

\section{Dependent variables}

Our dependent variable is innovation performance, whereas the variable of imitation is a mediator. We measure innovation performance by the percentage of annual sales generated from the introduction of new to the world type of new, and improved products (Cassiman and Veulegers, 2002; He and Wong, 2004) by aggregating two CIS indicators, the percentage of annual turnover generated through both new and significantly improved products with respect to their characteristics or intended uses, respectively. This includes significant improvements in technical specifications, components and materials, incorporated software, user friendliness or other functional characteristics (OECD, 2005). New products can be anchored in new knowledge or technologies, or based on new uses or combinations of existing knowledge or technologies (OECD, 2005). Significantly improved products can be intended to decrease unit costs of production or delivery, to increase quality, or to produce or deliver new or significantly improved products (OECD, 2005). The combined 
measure allows us to effectively capture the process innovation performance in addition to the outcome of radical innovation. The incremental aspect of innovation performance has been largely undervalued by previous innovation indicators, such as new product sales and patent counts, with a strong focus on measuring the outcome of product innovation (Autio et al., 2000; Rothaermel and Hess, 2007).

Compared with assessing innovation performance, measuring imitation can be rather challenging, as it is difficult to describe and quantify a firm's imitation activity due to the implicit nature of such behavior in the context of certain industries, such as the service industry. Unlike filing for a patent and/or reporting new product sales, firms tend to protect information on their imitation activities and are not obliged to distinguish imitation-related income in their balance sheets, in particular in the presence of strong intellectual protection regimes (Pisano, 2006). Following existing studies (Cappelli et al., 2014; Mahmood and Rufin, 2005), we proxy imitation by the percentage of product sales in total turnover that were new to the local firm but not new to its market derived from the CIS database. A product is considered as new to existing products in the market if it enhances the quality and/or variety of the functional characteristics or intended uses of those existing products in the market (OECD, 2005).

\section{Independent variables}

Foreign competition is measured using the concentration ratio, which is the total market share of the eight largest foreign firms in each sector as follows.

$$
\text { Concentration ratio }\left(\mathrm{CR}_{\mathrm{m}}\right)=\mathrm{S}_{1}+\mathrm{S}_{2}+\mathrm{S}_{3}+\ldots+\mathrm{S}_{\mathrm{m}}
$$

where $S_{m}$ is the market share of $m^{\text {th }}$ firm. $m=1,2,3, \ldots 8$; the lower the value of the concentration ratio, the higher the level of foreign competition. We used the inverse 
measure $\left(1-\mathrm{CR}_{\mathrm{m}}\right)$ such that a higher value indicates greater foreign competition (Bowen and Wiersema, 2005). The variable allows us to capture the intensity of foreign competition in an industry (Acs and Audretsch, 1988; Nickell, 1996).

We measure ACAP by a firm's $R \& D$ expenditure as a percentage of its total turnover (Cohen and Levinthal, 1990; Stock et al., 2001). We obtained data from the CIS survey that indicated the amount of expenditure in (1) intramural (in-house R\&D); (2) extramural R\&D; and (3) acquisition of external knowledge. We exclude extramural R\&D in the total R\&D expenditure, as such spending is usually used to outsource a firm’s R\&D activity with little indication of its ability to acquire, assimilate and apply new knowledge. To evaluate the focus of a firm's ACAP, and thus to isolate the interaction effect of ACAP more fully, we control for a firm's internal ACAP focus by creating a ratio of its R\&D expenditure dedicated to in-house R\&D over its total R\&D activity (Rothaermel and Alexandre, 2009).

In addition, we also control for local competition, technology gap, employee skills, size, sector, location, export intensity, imitation and innovation propensity. Detailed information on the measurements of our control variables is provided in Appendix 2.

\section{Analytical approach}

We used the OLS regression to estimate the impact of foreign competition on imitation as our dependent variable; the percentage of imitation related to sales, is a continuous variable. It is likely that local firms may self-select their imitation behaviours, and innovation outcomes may be affected by unobserved factors that influence local firms' imitation choices. Thus, to estimate the impact of local firms' imitation activities on their innovation performance, we adopted a two-stage selection 
model to correct for the potential self-selection biases (Heckman, 1979). Compared to alternative methods, such as the structural equation modelling methods, this approach effectively avoids the problems associated with a lack of widely accepted goodnessof-fit statistics with little latitude for error analysis (Bentler and Bonnet, 1980). Detailed explanations for our analytical approach are presented in Appendix 3.

\section{Results}

Table 1 presents the descriptive statistics and Pearson correlations of our variables.

Table 2 provides the descriptive statistics of our sample firms by industry. A distribution of foreign competition by industry is illustrated in Figure 2, based on its mean value during our sample period. Tables 3 and 4 report the results from our regression analysis of local firms' imitation and innovation performance. In Hypothesis 1a, we predict a positive impact of foreign competition on local firms' imitation. In Model 1, we find support for this hypothesis, as the coefficient of foreign competition is significant and positive ( $1.917, \mathrm{p}<0.05$ ), suggesting that increasing foreign competition has a positive impact on local firms’ imitation activities. In particular, one standard deviation increase in foreign competition leads to a 13.1 per cent increase in a firm's imitation activity. 
Table 1. Descriptive statistics and correlation matrix ${ }^{a}$

\begin{tabular}{|c|c|c|c|c|c|c|c|c|c|c|c|c|}
\hline Variable & 1 & 2 & 3 & 4 & 5 & 6 & 7 & 8 & 9 & 10 & 11 & 12 \\
\hline 1. Foreign competition $t_{t-2}(\mathrm{FC})$ & 1 & & & & & & & & & & & \\
\hline 2. Local competition $t_{t-2}(\mathrm{LC})$ & -0.593 & 1 & & & & & & & & & & \\
\hline 3. $\log \left(\mathrm{Gap}_{t-2}+1\right)$ & 0.030 & -0.051 & 1 & & & & & & & & & \\
\hline 4. Innovation performance & 0.196 & -0.134 & -0.030 & 1 & & & & & & & & \\
\hline 5. Imitation $t_{t-2}$ & 0.052 & -0.167 & 0.011 & 0.347 & 1 & & & & & & & \\
\hline 6. $\mathrm{ACAP}_{t-2}$ & 0.033 & -0.035 & 0.005 & 0.086 & 0.082 & 1 & & & & & & \\
\hline 7. Internal $\mathrm{ACAP}_{t-2}$ & 0.030 & -0.137 & -0.001 & 0.146 & 0.104 & 0.018 & 1 & & & & & \\
\hline 8. R\&D commitment & 0.011 & -0.112 & -0.001 & 0.120 & 0.080 & 0.079 & 0.095 & 1 & & & & \\
\hline 9. Size & 0.028 & 0.056 & 0.017 & 0.010 & 0.123 & -0.012 & 0.019 & 0.010 & 1 & & & \\
\hline 10. Employee skills & -0.011 & -0.137 & -0.002 & 0.210 & 0.209 & 0.018 & 0.255 & 0.239 & 0.081 & 1 & & \\
\hline 11. Export & 0.188 & -0.357 & 0.016 & 0.226 & 0.165 & 0.054 & 0.123 & 0.113 & 0.024 & 0.254 & 1 & \\
\hline 12. Location England & -0.184 & -0.013 & 0.040 & -0.351 & -0.098 & -0.075 & -0.055 & -0.040 & -0.037 & -0.032 & 0.026 & 1 \\
\hline Mean & 0.127 & 0.630 & 3.974 & 0.718 & 0.498 & 0.070 & 0.005 & 0.006 & 0.384 & 0.064 & 0.482 & 0.269 \\
\hline S.D. & 0.081 & 0.177 & 1.206 & 1.152 & 1.051 & 0.214 & 0.035 & 0.035 & 0.486 & 0.143 & 0.500 & 0.444 \\
\hline
\end{tabular}

${ }^{\mathrm{a}} \mathrm{N}=942$. The absolute value of each correlation greater than 0.04 is significant at $\mathrm{p}<0.05$ level.

Table 2. Descriptive statistics by industry

\begin{tabular}{|c|c|c|c|c|c|c|c|c|c|c|}
\hline \multirow[t]{2}{*}{ Variable } & \multicolumn{2}{|c|}{$\begin{array}{l}\text { Industry } 1 \\
\text { (80 firms) }\end{array}$} & \multicolumn{2}{|c|}{$\begin{array}{l}\text { Industry } 2 \\
\text { (77 firms) }\end{array}$} & \multicolumn{2}{|c|}{$\begin{array}{l}\text { Industry } 3 \\
\text { (62 firms) }\end{array}$} & \multicolumn{2}{|c|}{$\begin{array}{l}\text { Industry } 4 \\
\text { (38 firms) }\end{array}$} & \multicolumn{2}{|c|}{$\begin{array}{l}\text { Industry } 5 \\
\text { (57 firms) }\end{array}$} \\
\hline & Mean & S.D. & Mean & S.D. & Mean & S.D. & Mean & S.D. & Mean & S.D. \\
\hline Foreign competition $_{t-2}(\mathrm{FC})$ & 0.163 & .079 & .152 & 0.110 & 0.114 & 0.075 & 0.060 & 0.001 & .076 & $\overline{0.017}$ \\
\hline $\log \left(\operatorname{Gap}_{t-2}+1\right)$ & 3.782 & 1.141 & 4.638 & 1.232 & 3.847 & 1.160 & 2.322 & 1.109 & 3.227 & 1.143 \\
\hline Innovation performance & 1.009 & 1.205 & 0.550 & 1.108 & 0.773 & 1.264 & 0.472 & 0.984 & 0.332 & 0.895 \\
\hline Imitation $_{t-2}$ & 0.021 & 1.233 & & 0.793 & 0.516 & 1.068 & 0.246 & 0.753 & 0.523 & 1.080 \\
\hline Local competition $_{t-2}(\mathrm{LC})$ & 0.496 & 0.162 & 0.596 & 0.166 & 0.736 & 0.138 & 0.800 & 0.023 & 0.701 & 0.088 \\
\hline $\operatorname{ACAP}_{t-2}$ & 0.086 & 0.225 & 0.066 & 0.223 & 0.076 & 0.228 & 0.068 & 0.214 & 0.059 & 0.191 \\
\hline Internal $\mathrm{ACAP}_{t-2}$ & 0.009 & 0.030 & 0.001 & 0.006 & 0.003 & 0.022 & 0.000 & 0.001 & 0.010 & 0.055 \\
\hline R\&D commitment & 0.010 & 0.032 & 0.001 & 0.007 & 0.004 & 0.026 & 0.000 & 0.002 & 0.016 & 0.105 \\
\hline Size & 0.411 & 0.492 & 0.370 & 0.483 & 0.402 & 0.492 & 0.286 & 0.453 & 0.494 & 0.503 \\
\hline Employee skills & 0.064 & 0.113 & 0.021 & 0.056 & 0.032 & 0.090 & 0.019 & 0.058 & 0.204 & 0.272 \\
\hline Export & 0.796 & 0.403 & 0.371 & 0.484 & 0.376 & 0.486 & 0.236 & 0.426 & 0.723 & 0.450 \\
\hline Location England & 0.210 & 0.408 & 0.299 & 0.458 & 0.238 & 0.427 & 0.304 & 0.462 & 0.771 & 0.423 \\
\hline
\end{tabular}

“1” = Manufacturing, “2” = Repair of motor vehicles and motorcycles, “3” = Transportation and storage,

“4” = Information and communication, “5” = Professional, scientific and technical activities. 
Table 3. OLS regression of imitation and innovation performance ${ }^{a}$

\begin{tabular}{|c|c|c|c|c|c|c|}
\hline & $\begin{array}{l}\text { Model 1' } \\
\text { IM }\end{array}$ & $\begin{array}{l}\text { Model 2' } \\
\text { IP }\end{array}$ & $\begin{array}{l}\text { Model 3' } \\
\text { IP }\end{array}$ & $\begin{array}{l}\text { Model 4' } \\
\text { IP }\end{array}$ & $\begin{array}{l}\text { Model 5' } \\
\text { IP }\end{array}$ & $\begin{array}{l}\text { Model 6' } \\
\text { IP }\end{array}$ \\
\hline \multicolumn{7}{|l|}{ Independent variables } \\
\hline Foreign competition $_{t-2}$ & $\begin{array}{l}1.917^{*} \\
(0.802)\end{array}$ & & $\begin{array}{c}6.582^{* *} \\
(1.885)\end{array}$ & $\begin{array}{l}4.000^{* *} \\
(1.575)\end{array}$ & $\begin{array}{c}3.269 * \\
(1.422)\end{array}$ & $\begin{array}{l}3.284^{* *} \\
(1.347)\end{array}$ \\
\hline \multicolumn{7}{|l|}{ Mediating variables } \\
\hline Imitation $_{t-2}$ & & & & $\begin{array}{l}0.410^{* * *} \\
(0.099)\end{array}$ & $\begin{array}{c}0.823^{* *} \\
(0.318)\end{array}$ & $\begin{array}{l}1.028^{* *} \\
(0.363)\end{array}$ \\
\hline Imitation square $_{t-2}$ & & & & & $\begin{array}{l}-0.145^{*} \\
(0.077)\end{array}$ & $\begin{array}{c}-0.197 * \\
(0.090)\end{array}$ \\
\hline \multicolumn{7}{|l|}{ Conditional mediating effect } \\
\hline $\operatorname{ACAP}_{t-2} \times$ Imitation $_{t-2}$ & & & & & & $\begin{array}{l}-1.533^{*} \\
(0.740)\end{array}$ \\
\hline $\operatorname{ACAP}_{t-2} \mathrm{x}$ Imitation square ${ }_{t-2}$ & & & & & & $\begin{array}{r}0.405^{\dagger} \\
(0.219)\end{array}$ \\
\hline \multicolumn{7}{|l|}{ Control variables } \\
\hline Domestic competition $_{t-2}$ & $\begin{array}{c}0.413^{\dagger} \\
(0.223)\end{array}$ & $\begin{array}{l}2.011^{* *} \\
(0.651)\end{array}$ & $\begin{array}{l}2.664^{* *} \\
(0.813)\end{array}$ & $\begin{array}{l}2.118^{* *} \\
(0.815)\end{array}$ & $\begin{array}{c}1.704^{*} \\
(0.721)\end{array}$ & $\begin{array}{c}1.828^{*} \\
(0.720)\end{array}$ \\
\hline $\operatorname{ACAP}_{t-2}$ & $\begin{array}{c}0.667 * \\
(0.268)\end{array}$ & $\begin{array}{r}0.404^{\dagger} \\
(0.246)\end{array}$ & $\begin{array}{c}0.365^{*} \\
(0.242)\end{array}$ & $\begin{array}{r}0.160 \\
(0.230)\end{array}$ & $\begin{array}{r}0.126 \\
(0.228)\end{array}$ & $\begin{array}{r}0.518 \\
(0.319)\end{array}$ \\
\hline Internal $\mathrm{ACAP}_{t-2}$ & $\begin{array}{r}1.246 \\
(0.980)\end{array}$ & $\begin{array}{l}-4.791^{* *} \\
(1.797)\end{array}$ & $\begin{array}{l}-3.746^{*} \\
(1.668)\end{array}$ & $\begin{array}{c}-2.447^{\dagger} \\
(1.515)\end{array}$ & $\begin{array}{l}-2.345 \\
(1.518)\end{array}$ & $\begin{array}{r}-2.491 \\
(1.518)\end{array}$ \\
\hline $\operatorname{Gap}_{t-2}$ & $\begin{array}{r}0.000 \\
(0.000)\end{array}$ & $\begin{array}{r}0.000 \\
(0.000)\end{array}$ & $\begin{array}{r}0.000 \\
(0.000)\end{array}$ & $\begin{array}{c}0.000^{*} \\
(0.000)\end{array}$ & $\begin{array}{r}0.000^{\dagger} \\
(0.000)\end{array}$ & $\begin{array}{r}0.000^{\dagger} \\
(0.000)\end{array}$ \\
\hline R\&D commitment com $_{t-2}$ & $\begin{array}{c}1.178^{*} \\
(0.567)\end{array}$ & $\begin{array}{l}4.063^{* * *} \\
(0.963)\end{array}$ & $\begin{array}{l}3.407^{* * *} \\
(0.794)\end{array}$ & $\begin{array}{l}2.293^{* * *} \\
(0.622)\end{array}$ & $\begin{array}{l}2.021^{* * *} \\
(0.570)\end{array}$ & $\begin{array}{l}2.097^{* * *} \\
(0.553)\end{array}$ \\
\hline Size $_{t-2}$ & $\begin{array}{r}-0.199 \\
(0.124)\end{array}$ & $\begin{array}{r}0.053 \\
(0.098)\end{array}$ & $\begin{array}{r}0.024 \\
(0.095)\end{array}$ & $\begin{array}{r}0.073 \\
(0.102)\end{array}$ & $\begin{array}{r}0.035 \\
(0.097)\end{array}$ & $\begin{array}{r}0.037 \\
(0.096)\end{array}$ \\
\hline Sector & Yes & Yes & Yes & Yes & Yes & Yes \\
\hline Employee skills $_{t-2}$ & $\begin{array}{l}1.365^{* *} \\
(0.533)\end{array}$ & $\begin{array}{l}2.649^{* * *} \\
(0.526)\end{array}$ & $\begin{array}{l}2.546^{* * *} \\
(0.505)\end{array}$ & $\begin{array}{l}1.665^{\text {*** }} \\
(0.370)\end{array}$ & $\begin{array}{l}1.611^{* * *} \\
(0.369)\end{array}$ & $\begin{array}{l}1.638^{* * *} \\
(0.367)\end{array}$ \\
\hline Export $_{t-2}$ & $\begin{array}{c}0.627^{\dagger} \\
(0.314)\end{array}$ & $\begin{array}{l}1.263^{* * * *} \\
(0.339)\end{array}$ & $\begin{array}{l}1.017^{* * *} \\
(0.280)\end{array}$ & $\begin{array}{c}0.674^{* *} \\
(0.232)\end{array}$ & $\begin{array}{c}0.552^{*} \\
(0.216)\end{array}$ & $\begin{array}{l}0.576^{* *} \\
(0.210)\end{array}$ \\
\hline Location England & $\begin{array}{r}-0.687 \\
(0.460)\end{array}$ & $\begin{array}{l}1.416^{* * *} \\
(0.329)\end{array}$ & $\begin{array}{l}1.212^{* * *} \\
(0.284)\end{array}$ & $\begin{array}{c}0.856^{* *} \\
(0.226)\end{array}$ & $\begin{array}{l}0.763^{* * *} \\
(0.208)\end{array}$ & $\begin{array}{l}0.805^{\text {*** }} \\
(0.209)\end{array}$ \\
\hline Inverse Mills ratio & & $\begin{array}{l}3.559 * * * \\
(1.170)\end{array}$ & $\begin{array}{c}764^{* *} \\
(0.958)\end{array}$ & $\begin{array}{l}1.537^{* * *} \\
(0.766)\end{array}$ & $\begin{array}{l}1.258^{* * *} \\
(0.730)\end{array}$ & $\begin{array}{l}1.367^{* * *} \\
(0.627)\end{array}$ \\
\hline 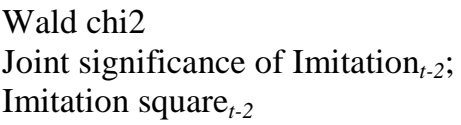 & $193.13^{* * *}$ & 413. $43^{* * *}$ & $419.80^{* * *}$ & $490.57^{* * *}$ & $\begin{array}{r}488.66^{* * *} \\
19.03^{* * *}\end{array}$ & $\begin{array}{c}492.13^{* * *} \\
20.02^{* * *}\end{array}$ \\
\hline $\mathrm{R}^{2}$ & 0.124 & 0.168 & 0.170 & 0.171 & 0.173 & 0.177 \\
\hline
\end{tabular}

${ }^{\mathrm{a}} \mathrm{N}=942 . \quad{ }^{\dagger} p<0.10, \quad * p<0.05, \quad * * p<0.01, \quad * * * p<0.001$.

Standardized errors are reported in parentheses.

IP = Innovation Performance

$\mathrm{IM}=$ Imitation 


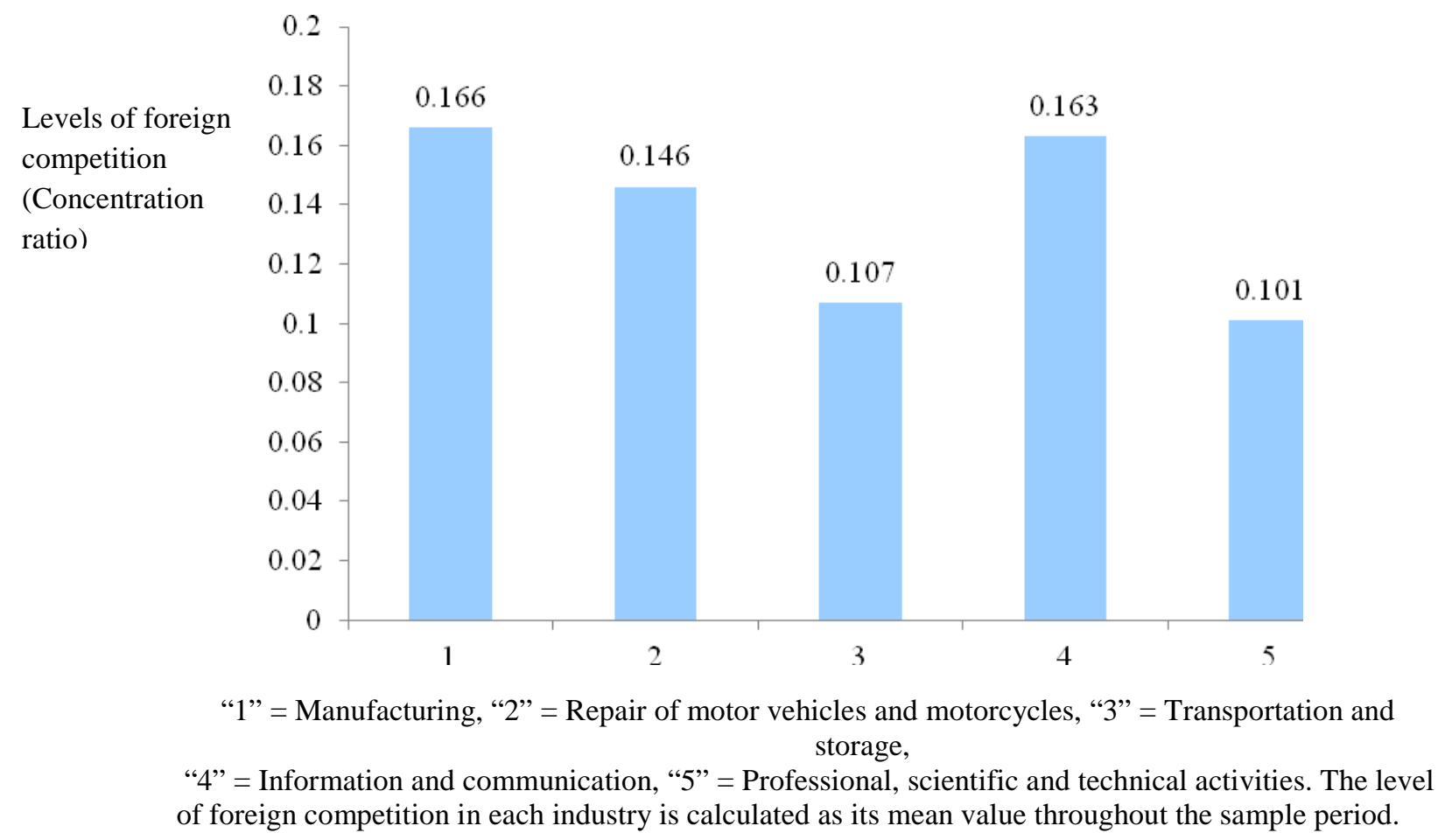

Figure 2. Distribution of foreign competition by industry during the period 20022010

Hypothesis 1b predicts that imitation resulting from foreign competition has an inverted U-shaped relationship with local firms' innovation performance. In Model 5, we find that innovation performance is positively related to the linear term of LPLWDWLRQ. 823, $\mathrm{p}<0.01$ ) but negatively related to the squared term of imitation $-0.145, \mathrm{p}<0.05)$, and their relationship is highly significant in each case. One standard deviation increase in the linear term of imitation leads to a 60 per cent increase in a firm's innovation performance, whereas one standard deviation increase in the squared term of imitation results in a 33.2 per cent decrease in a firm's innovation performance. These results suggest that imitation contributes to local firms' innovation performance at a moderate level of imitation; however, such benefits diminish once the level of imitation reaches a certain threshold. 


\section{Mediation analyses}

To test the mediation effects of imitation (Hypothesis 1c), we followed the conventional casual step methods using the stepwise approach introduced by Baron and Kenny (1986). According to this approach, a test for mediation effect must meet three conditions: (1) if the independent variable (foreign competition) significantly predicts the mediating variable (local firms’ imitation); (2) the independent variable (foreign competition) significantly predicts the dependent variable (local firms' innovation performance); (3) the mediating variable (local firms’ imitation) significantly predicts the dependent variable (local firms’ innovation performance) while controlling for the effect of the independent variable (foreign competition). We have estimated these three conditions independently in Models 1, 3 and 6 following the same order (Table 3). In line with Baron and Kenny’s (1986) criteria, the results of the stepwise test (Models 1, 3 and 6 in Table 3) confirm that imitation significantly mediates the relationship between foreign competition and local firms' innovation performance. This is shown by (1) the significant coefficient of foreign competition ( $=1.917, \mathrm{p}<0.05)$ in predicting imitation (Model 1), and (2) the significant coefficient of foreign competition ( 6.582, $\mathrm{p}<0.01$ ) in predicting innovation performance (Model 3), and (3) significant coefficient of imitation (liner term 1.028, $\quad \mathrm{p}<0.01$; squared WHUP -0.197, $\mathrm{p}<0.05$ ) on local firms’ innovation performance when controlling for foreign competition (Model 6).

In Hypothesis 2, we postulate that for local firms with less ACAP, the curvilinear relationship between imitation and innovation performance is more pronounced than for those with greater ACAP. The results from Model 6 in Table 3 show a significant and negative interaction between ACAP and the linear term of imitation ( $-\quad 1.533, \mathrm{p}<0.05)$, but a positive and marginally significant interaction 
between ACAP and the squared term of imitation (S)

. In addition to

the increase of the direct effects, one standard deviation increase in the interaction effect of ACAP on the linear imitation-innovation relationship causes a 13 per cent decrease in a firm's innovation performance; by contrast, one standard deviation increase in the interaction effect of ACAP on the squared imitation-innovation relationship incurs a 11.4 per cent increase in its innovation performance. These findings suggest that ACAP diminishes the positive impact of imitation on local firms' innovation performance up to a certain level of imitation and mitigates the negative impact of imitation on local firms' innovation performance at a high level of imitation. Thus, Hypothesis 2 is supported. To gain further insights into the interaction between imitation and ACAP, we plotted the significant results obtained in Model 6 (Table 3), which are depicted in Figure 3. In the front of the figure, imitation has an inverted U-shaped relationship with local firms' innovation performance. As ACAP increases, both the positive and negative relationships between imitation and innovation performance become weaker, and eventually this inverted U-shaped relationship is reversed. In support of Hypothesis 2, the graph further demonstrates that ACAP substitutes for imitation in contributing to local firms’ innovation performance at a low level of imitation, whereas at a high level of imitation, ACAP complements imitation as a means of enhancing local firms’ innovativeness.

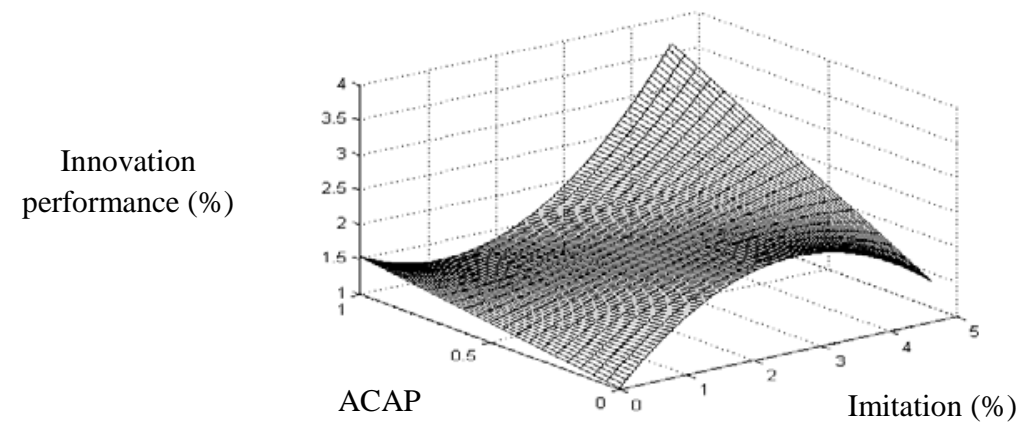

Figure 3. The interaction effect of ACAP on the relationship between imitation and innovation performance 


\section{Discussion and conclusions}

Our findings suggest that imitation is an explanatory mechanism of the relationship between foreign competition and local firms' innovation performance. Moreover, our results also show that although imitation is less costly than innovation, excessive imitation activities exhaust a firm's opportunities to keep up with changing market conditions (Lieberman and Asaba, 2006). Intriguingly, our results show that the optimum levels of imitation for facilitating local firms' innovation performance are more than one standard deviation above the mean of imitation within our sample firms. Additionally, we find that the strength of this relationship is conditional on local firms’ ACAP. Our findings suggest that ACAP reduces the importance of a moderate level of imitation for local firms’ innovation performance. However, strong ACAP enables local firms with excessive imitation to gain more innovationenhancing benefits from imitation, thus strengthening the positive impact of imitation on innovation performance.

Implications for competition, imitation and innovation research

Our study makes a number of contributions to existing knowledge on competition, imitation and innovation. First, the explanatory power of both information-based and competitive rivalry-based theories lies in their ability to predict firms' motivation to imitate and the subsequent performance implications under different competitive scenarios (Bikhchandani et al., 1992; Baum and Haveman, 1997; Liberman and Asaba, 2006). However, these theories are unable to take more explicit account of indirect performance implications of imitation activity undertaken associated with each type of incentive. Our study takes a significant step forward towards closing this gap by examining the mediating effect of local firms' imitation activity on the foreign 
competition-innovation relationship. Our findings identify the role played by imitation in filtering the effect of foreign competition on local firms' innovation activities. In this sense, our study enhances the precision of the theoretical predictions of information-based and competitive rivalry-based theories on the indirect performance implications of firms' imitation activity. The findings also provide empirical support for previously untested contentions that local firms are able to retaliate against foreign rivals through creatively imitating their knowledge and/ business ideas (Phene et al., 2006; Kale and Little, 2007).

Moreover, our study also helps to explain the mixed findings of the impact of foreign competition on firms' innovation activities. Some studies found that foreign competition encourages local firms' innovation activities (Nickell, 1996; Liu and Buck, 2007; Dawson and Larke, 2004), while others reported a negative relationship between foreign competition and innovation (Schumpeter, 1950; Hinloopen and Vandekerckhove, 2009). Early theories tended to explain this discrepancy using the distance to technology frontier (Aghion et al., 1997), according to which foreign competition contributes to the innovation performance of neck and neck competitors, but discourages the innovation of laggard firms. These explanations fail to capture the potential 'learning effect' of laggard firms (Cohen et al., 1990). This missing perspective is of pivotal importance in addressing the increasing phenomena characterized by the diminishing line of clarity between imitation and innovation (Bessen and Maskin, 2009; Casadesus-Masanell and Zhu, 2013). Our study thus enriches and refines organizational learning theory by emphasizing the innovationrelated benefits of learning from imitation. In doing so, we further contribute to the development of more robust perspectives that can explain the complex relationships between imitation and innovation. 
A second important theoretical implication is that the relationship between imitation and innovation performance is non-linear and subject to diminishing returns in innovation. The exclusivity of imitation to innovation has been overmagnified by previous studies (March, 1991; Levinthal and March, 1993; Deephouse, 1999). Although the benefits of imitation to innovation have received increasing attention from recent studies (Bessen and Maskin, 2009; Semandeni and Anderson, 2010), they have been largely overlooked at the firm level as opposed to the country level (Kale and Little, 2007), with few studies looking into the potential link between imitation and innovation. Thus, our study extends this line of research by providing a more complete account of the relationship between imitation and innovation performance. We shed light on this critical research gap by providing rationale and empirical evidence of a curvilinear (inverted U-shaped) relationship, with innovation performance being highest at intermediate, as opposed to maximum levels of imitation.

Finally, our analysis reveals the complex interaction between imitation and ACAP in advancing innovation at the firm level. On the one hand, our results suggest that unless local firms intensively engage in imitation, ACAP substitutes for imitation as a means of enhancing innovation. Whilst prior literature views ACAP as a necessary complement to external knowledge acquisition through imitation, partnership and so on (Dahlander and Gann, 2010; Chesbrough and Crowther, 2006), it is less clear whether there could be a substitution effect with ACAP replacing imitation. A potential substitution effect may prevail because well-developed internal know-how can crowd out external knowledge sourcing as an effective innovation strategy (Chesborough, 2003; Veugelers, 1997; Veugelers and Cassiman, 1999). Our study advances this body of research by unpacking the existence of such relationships. 
On the other hand, our analysis shows that there is a complementary relationship between ACAP and imitation in contributing to local firms' innovation performance at high levels of imitation. This finding indicates the boundary condition for exhaustive imitation: firms need to develop certain levels of ACAP in order to successfully exploit external knowledge acquired through imitation and convert it into new products or services. Additionally, our finding highlights the fact that firms vary in the extent to which they can imitate and incorporate imitation as part of their innovation strategy - an aspect that is largely neglected by prior research. Our study thus fills this important research gap by teasing out the conditions under which ACAP complements or substitutes for imitation as an enabler of firms' innovation performance.

\section{Managerial implications}

The findings from our study have important managerial implications for practitioners and managers. First, foreign competition represents a source of new knowledge and local firms should be open minded and learn from foreign rivals. The key message is that an appropriate level of imitation resulting from competition is desirable and helps local firms enhance innovation performance, given that they have the ACAP to exploit the imitated knowledge. It is important for managers to be aware that the extent to which firms' own R\&D substitutes for imitation in contributing to firms’ innovation may vary at different levels of imitation. Therefore, maintaining the right balance of internal R\&D and imitation is crucial to boosting innovation performance. This makes it necessary for these managers to constantly evaluate the levels of firms' own R\&D and imitation activity, to ensure that they are well matched with regard to the goal of optimizing the firms' innovation performance. Second, while it is 
important to invest in R\&D to develop ACAP, managers should avoid the 'capability trap’ by overly emphasising internal capability building while overlooking the importance of external knowledge sourced from foreign rivals. The increasing foreign competition in the domestic market is inevitable due to the accelerated process of globalization. Instead of passively responding to such a growing trend, managers in these economies should enhance firms' innovation performance through appropriate levels of imitation, and balance their internal and external ACAP to maximize the positive effect of competition on their innovation filtered through imitation.

\section{Limitations and future research directions}

Our study is, however, subject to a number of limitations, which in turn open up new opportunities for future research. First, we are unable to differentiate between the sources of foreign competition; for example, learning from emerging market rivals such as China and India could be captured differently from those that originate from developed economies, typified by the US and western European countries. Future research could further explore the different impacts of foreign competition on imitation and innovation performance. Second, due to the limitation of the CIS survey, we were unable to obtain information on firm age. However, the conditional mediating effect of imitation on innovation performance may be more severe for startup firms than established businesses because of the existence of structural inertia (Delacroix, 1993; Hannan and Freeman, 1984). This opens an interesting avenue for a thorough investigation of the age effect. Finally, in this study, we could only measure imitation by the percentage of sales generated from products that are new to a firm but not to its market, due to the limitation of the CIS dataset. The measurement, however, fails to rule out the possibility that many companies may make similar contributions 
to the existing state-of-the-art products simultaneously and completely independently, without imitation. Similarly, we measure absorptive capacity conventionally using R\&D intensity - a measurement which indicates firms’ overall knowledge acquisition or assimilation ability, but fails to capture the different dimensions of ACAP, in particular a firms' ability to transform and exploit newly acquired and assimilated knowledge, as repeatedly noted by many studies (Zahra and George, 2002; Jansen et al., 2005; Newey and Zahra, 2009) Future research should generalize our findings using more quality-based measures of firms’ imitation activities and ACAP. 


\section{Appendix 1: Industry classifications of our sample firms and matching methods}

These firms cover five major one-digit UK SIC (2007) industries, i.e. the manufacturing industry (C), the repair of motor vehicles and motorcycles industry $(G)$, the transportation and storage industry $(H)$, the information and communication industry (J) and the professional, scientific and technical activities industry (M). Information on foreign competition over the 2002 to 2010 period was collected from the ABS database. CIS respondents were matched bi-annually on the basis of their SIC (2007) codes. The foreign ownership (dummy) and turnover variables in the ABS database allowed us to identify foreign firms and aggregate their turnover as a percentage of overall market sales according to sectors using the SIC (2007) code.

\section{Appendix 2: Control variables}

We measure local competition using the same inverse measurement approach as foreign competition ((1-CR $\left.\mathrm{CR}_{\mathrm{m}}\right)$ (Bowen and Wiersema, 2005). We capture a local firm’s technology gap by the difference between the average productivity (firm annual value added/the number of employees, weighted by firm asset size) of foreign entrants in a SIC code industry sector and the productivity of a domestic firm in the same sector (Aghion and Howitt, 2010). Size is measured by a firm's total number of full-time employees. To capture the location effect on innovation and imitation, we created two location dummies — England and other regions - to differentiate firms located in each area (coded 1) from the rest (coded 0). Export intensity is operationalized as the total exports to sales ratio. To control for any sectoral effect, we also include a set of twelve industry dummy variables. Innovation propensity is a dummy variable, taking the value of 1 if a firm engages in innovation activities and 0 otherwise. In a similar vein, we created a dummy variable to capture a firm’s 
imitation propensity. The variable takes the value of 1 if a firm engages in imitation activities and 0 otherwise.

\section{Appendix 3: Detailed explanations of our analytical approach}

In the first stage, we used a Probit model to capture firms' imitation propensity. We included barriers to innovation and all independent variables in the selection equation. Barriers to innovation are measured by whether or not firms perceived costs, knowledge, market and other factors act as constraints to their innovation activities (1 $=$ Yes, 0 otherwise). The inclusion of these variables in the selection equation helps us with model identification, while correcting for sample selection (Wooldridge, 2003; Heckman, 1979). In the second stage, we estimated innovation performance using an OLS regression as our dependent variable, the percentage of innovation-related sales (from new products and processes) is a continuous variable, taking values ranging from 0 to 1.We incorporated the inverse Mills ratio calculated in the first stage Probit model as a regressor in our second stage model estimating firms’ innovation performance to control for the self-selection biases. In addition, we included return on new products as an exclusive variable in our first stage selection model to avoid overidentification problems and correct for sample selection. Return on new products is measured by the ratio of new product sales to innovation expenditure. To control for potential endogeneity biases, we used conditional mixed process (CMP) estimation to account for the assumption that the dependent variables are endogenous in the system (Roodman, 2007). Specifically, we used the lagged values ( $t$-2) of industry averaged innovation performance and lagged $(t-2)$ innovation-related sales as instruments (Arellano and Bond, 1991). Results from Hansen tests of overidentification restrictions did not reject the null hypothesis of valid instruments for all equations 
included in our modelling system. The estimation method is more efficient and accurate in addressing endogeneity problems than the two-stage least-squares regression by offering far more flexibility in model construction. We are able to instrument both the linear and squared terms of imitation in separate equations with different sets of instruments. Finally, we lagged the imitation variable and all the independent variables in the imitation model for two years. This can provide more consistent estimates of coefficients and identify causal relationships between imitation and firms' innovation performance (Leonidou and Katsikeas, 1996). Additionally, we estimated the system of equations using the generalized method of moments (GMM) regression, and the results obtained are consistent with those reported in Table 3 (Model 7).

\section{Appendix 4: Robustness checks}

To assess the validity of the inverted U-shaped relationship between imitation and innovation performance, we performed several robustness checks. First, we tested the joint significance of the linear and squared terms of the imitation variable (Sasabuchi, 1980). The result is statistically significant, providing strong support for Hypothesis 2. Second, we estimated the extreme point of imitation, and calculated confidence intervals based on Fieller's standard error and the Delta method (Lind and Mehlum, 2010). The results from both analyses suggest that imitation values are within the limits of our data. Third, we tested the robustness of our results across the five main industries. The results for each industry are consistent with our main results in terms of the direction and significance level of each independent variable. Finally, we examined the variance inflation factors (VIFs) of each model after our regression analysis. All VIF scores are below 3, which is much lower than 10, the commonly 
used rule of thumb for multicollinearity (Cohen et al., 2003). Thus, our analyses are unlikely to have a serious problem with multicollinearity.

Table 4. The interaction of ACAP on the indirect effect of foreign competition on local firms' innovation performance through their imitation activities

\begin{tabular}{|c|c|c|c|c|c|c|}
\hline & \multicolumn{6}{|c|}{ DV: Innovation performance } \\
\hline & \multicolumn{6}{|c|}{ Mediator: Imitation } \\
\hline & $\begin{array}{c}\text { Observed } \\
\text { Coef. }\end{array}$ & Bias & $\begin{array}{c}\text { Bootstrap } \\
\text { SE }\end{array}$ & $95 \%$ & CI & \\
\hline $\begin{array}{l}\text { Foreign competition at low levels of } \\
\text { ACAP }\end{array}$ & 1.597 & 0.015 & 0.552 & $\begin{array}{l}0.629 \\
0.652\end{array}$ & $\begin{array}{l}2.792 \\
2.827\end{array}$ & $\begin{array}{l}\mathrm{P} \\
\mathrm{BC}\end{array}$ \\
\hline $\begin{array}{l}\text { Foreign competition at moderate levels } \\
\text { of ACAP }\end{array}$ & 1.657 & -0.011 & 0.530 & $\begin{array}{l}0.704 \\
0.774\end{array}$ & $\begin{array}{l}2.756 \\
2.875\end{array}$ & $\begin{array}{l}\mathrm{P} \\
\mathrm{BC}\end{array}$ \\
\hline $\begin{array}{l}\text { Foreign competition at high levels of } \\
\text { ACAP }\end{array}$ & 1.717 & -0.036 & 0.590 & $\begin{array}{l}0.660 \\
0.807\end{array}$ & $\begin{array}{l}2.957 \\
3.156\end{array}$ & $\begin{array}{l}\mathrm{P} \\
\mathrm{BC}\end{array}$ \\
\hline
\end{tabular}

Note: $\mathrm{CI}=$ confidence interval; $\mathrm{P}$ = percentile CI; BC = bias-corrected CI.

Additionally, Table 4 presents the results for the conditional mediation model for firm innovation performance. To formally test if the inverted U-shape mediating effect ${ }^{1}$ of imitation on the relationship between foreign competition and innovation performance is stronger for firms with high levels of ACAP, we performed the Preacher et al. (2007) and Hayes (2013) moderated-mediation test and used 5,000 bootstrap resamples and a bias-corrected and accelerated 95 per cent confidence interval. The conditional indirect effect of foreign competition on innovation performance is estimated at low, moderate, and high levels of ACAP._The analysis replicates the previous results showing that imitation mediates the relationship between foreign competition and firm innovation performance at different levels of ACAP. In particular, the results in Table 4 show that the conditional indirect effect of foreign competition on innovation performance increases as the level of a firm's ACAP increases (indirect effect $=1.717, \mathrm{p}<0.01$ at a high level of ACAP; indirect 
effect $=1.675, \mathrm{p}<0.01$ at a moderate level of ACAP; indirect effect $=1.597, \mathrm{p}<0.01$ at a low level of ACAP). We also performed the moderated-mediation test using the normal theory approach, with equivalent results.

\section{Appendix 5: Supplementary analyses of the temporal aspects}

To examine the temporal relationships that may potentially exist among our variables, we undertook several supplementary analyses. First, we tested whether the effect of foreign competition on imitation is stronger for local firms with high levels of absorptive capacity, but found no support for this conjecture. Our results suggest that foreign competition contributes to the imitation activities of local firms with different levels of absorptive capacity. Second, in the context of our study, we argue that engagement with imitation does not necessarily enhance firms’ absorptive capacity. Imitating firms may not need to transform the knowledge but can use it as it is, in particular when imitation is accomplished for the purpose of maintaining competitive parity or limiting rivalry (Peteraf, 1993; Baum and Haveman, 1997; Head et al., 2002). In this case, the exploration of external knowledge does not require the firms to undertake the complex and demanding task of knowledge transformation (Zahra and George, 2002). However, we cannot completely dispel the possibility that engagement in imitation may require the development of ACAP. To assess the direction of causality between ACAP and imitation, we followed Landis and Dunlap's approach (2000). We set imitation as an independent variable and ACAP as the dependent variable and tested the effect of the new independent variable on the new dependent variable. The results show that the reverse relationship is insignificant, suggesting that reverse causality is of minimal concern in our study (Cao et al., 2009). 


\section{References}

Abrahamson, E. (1996). 'Management Fashion', Academy of Management Review, 21, pp. 254-285.

Acs, Z. J. and D. B. Audretsch, (1998). 'Innovation in large and small firms: an empirical analysis', The American Economic Review, 78, pp. 678-690.

Aghion, P., N. Bloom, R. Blundell, R.Griffith and P. Howitt (2005). 'Competition and Innovation: an Inverted-U Relationship', Quarterly Journal of Economics, 120, pp. 701-728.

Aghion, P., C. Harris, P. Howitt and J. Vickers (2001). 'Competition, imitation and growth with step-by-step innovation’, Review of Economic Studies, 68, pp. 467-492.

Aghion, P., C.Harris and J. Vickers (1997). 'Competition and Growth with Step-bystep Innovation: An Example', European Economic Review, 41, pp. 771-782.

Aghion, P. and P. Howitt (2006). 'Joseph schumpeter lecture appropriate growth policy: A unifying framework', Journal of the European Economic Association, 4, pp. 269-314.

Anand, J., Mesquita, L. F., and R. S. Vassolo (2009). 'The dynamics of multimarket competition in exploration and exploitation activities', Academy of Management Journal, 52, pp. 802-821.

Argote, L. (1999). Organizational Learning: Creating, Retaining, and Transferring Knowledge. Boston: Kluwer Academic.

Aronson, E., T. D.Wilson and R. M. Akert (2005). Social Psychology. Fifth Edition. New Jersey: Pearson Education International.

Atuahene-Gima, K. and H. Li (2004). 'Strategic decision comprehensiveness and new product development outcomes in new technology ventures', Academy of Management Journal, 47, pp. 583-597.

Audretsch, B. (1998). 'Agglomeration and the location of innovative activity', Oxford Review of Economic Policy, 14, pp. 18-29.

Autio, E., H. J. Sapienza and J. G. Almeida (2000). 'Effects of age at entry, knowledge intensity, and imitability on international growth', Academy of Management Journal, 43, pp. 909-924.

Axelrod, R. (1984). The Evolution of Cooperation. New York, US: Basic Books.

Barney, J. B. (1991). 'Firm resources and sustained competitive advantage', Journal of Management, 17, pp. 99-120.

Barringer, B. R. and R. D. Ireland (2008). Entrepreneurship: Successfully launching new ventures. New Jersey: Pearson Prentice Hall.

Baum, J. A. C. and H. A. Haveman (1997). 'Love Thy Neighbor? Differentiation and Agglomeration in the Manhattan Hotel Industry, 1989-1990'. Administrative Science Quarterly, 42, pp. 304-338.

Bessen, J. and E. Maskin, (2009). 'Sequential innovation, patents, and imitation', The RAND Journal of Economics, 40, pp. 611-635.

Bikhchandani, S., D. Hirshleifer and I. Welch (1998). 'Learning from the behavior of others: conformity fads and informational cascades', Journal of Economic Perspectives, 12, pp. 151-170.

Bowen, H. P. and W. F. Wiersema (2005). 'Foreign-based competition and corporate diversification strategy’, Strategic Management Journal, 26, pp. 1153-1171.

Caloghirou, Y., I. Kastelli and A. Tsakanikas (2004). 'Internal capabilities and external knowledge sources: complements or substitutes for innovative performance?', Technovation, 24, pp. 29-39. 
Brandenburger, A. and B. Nalebuff (1996). Co-Opetition: A Revolution Mindset That Combines Competition and Cooperation, Cambridge, MA: Harvard Business Press.

Cappelli, R., D. Czarnitzki and K. Kraft (2014). 'Sources of spillovers for imitation and innovation', Research Policy, 43, pp. 115- 120.

Cao, Q., E. Gedajlovic and H. Zhang (2009). 'Unpacking organizational ambidexterity: Dimensions, contingencies, and synergistic effects'. Organization Science, 20, pp. 781-796.

Carlin, W., M. E. Schaffer and Seabright, P. (2004). 'A Minimum of Rivalry: Evidence from Transition Economies on the Importance of Competition for Innovation and Growth', C.E.P.R. Discussion Papers. CEPR Discussion Paper 4343. London: CEPR.

Casadesus-Masanell, R. and F. Zhu (2013). 'Business model innovation and competitive imitation: The case of sponsor-based business models', Strategic Management Journal, 34, pp. 464-482.

Cassiman, B. and R. Veugelers (2002). 'Complementarity in the innovation strategy: internal RandD, external technology acquisition and co-operation in R\&D'. In KULeuven and CEPR Discussion Paper 3284.

Chang, S. J. and D. Xu (2008). 'Spillovers and competition among foreign and local firms in China', Strategic Management Journal, 29, pp. 495-519.

Chesbrough, H. and A. K. Crowther (2006). 'Beyond high tech: early adopters of open innovation in other industries', $R \& D$ Management, 36, pp. 229-236.

Clercq, D. D., Sapienza, H. J., Yavuz, R. I. and L. Zhou (2012). 'Learning and knowledge in early internationalization research: Past accomplishments and future directions', Journal of Business Venturing, 27, pp. 143-165.

Cohen, M. D. and P. Bacdayan, (1994). 'Organizational routines are stored as procedural memory: Evidence from a laboratory study', Organization Science, 5, pp. $554-568$

Cohen, W. M. and D. A. Levinthal (1990). 'Absorptive capacity: a new perspective on learning and innovation', Administrative Science Quarterly, 35, pp. 128152.

Cohen, M. D. and L. S. Sproull (1991). Organizational Learning, Thousand Oaks, CA: Sage,

Csaszar, F. and N. Siggelkow (2010). 'How much to copy? Determinants of effective imitation breadth', Organization Science, 21, pp. 661-676.

Daft, R. L. (2005). The leadership experience (3rd ed.), Mason, OH: South-Western.

Dahlandera, L. and M. D. Gannb (2010). 'How open is innovation?', Research Policy, 39, pp. 699-709.

Damanpour, F. (2010). 'Competition on product and process innovations', British Journal of Management, 21, pp. 996-1010.

Dasgupta, P. and J. Stiglitz (1980). 'Uncertainty, industrial structure, and the speed of R\&D', Bell Journal of Economics, 11, pp. 1-28.

Davidson, C. and P. Segerstrom (1998). 'R\&D Subsidies and Economic Growth', RAND Journal of Economics, 29, pp. 548-577.

Dawson, J. and R. Larke (2004). 'Japanese retailing through the 1990s: Retailer performance in a decade of slow growth', British Journal of Management, 15, pp. 73-94.

DeCarolis, D. M. (2003). 'Competencies and imitability in the pharmaceutical industry: An analysis of their relationship with firm performance', Journal of Management, 29, pp. 27-50. 
Deephouse, D. L. (1999). 'To be Different, or to be the Same? It's a Question (and Theory) of Strategic Balance', Strategic Management Journal, 20, pp. 147166.

Delacroix, J. (1993). 'The European Subsidiaries of American Multinationals: An Exercise in Ecological Analysis', pp. 105-135 in Ghoshal, S. and D. Eleanor Westney (1993). Organization Theory and the Multinational Corporation. New York: St. Martin’s Press.

Dell'Era, C. and R. Verganti, (2007). 'Strategies of Innovation and Imitation of Product Languages', Journal of Product Innovation Management, 24, pp. 580599.

Derfus, P. J., P. G. Maggitti, C. M. Grimm and K. G. Smith (2008). 'The red queen effect: competitive actions and firm performance', Academy of Management Journal, 51, pp. 61-80.

Driffield, N., J. Love and Y. Yang (2014). 'Technology sourcing and reverse productivity spillovers in the MNE: Global or regional phenomenon?', British Journal of Management, 25, pp. S24-S41.

Easley, D. and J. Kleinberg (2010). Networks, Crowds, and Markets: Reasoning about a Highly Connected World. New York, US: Cambridge University Press.

Enkel, E., O. Gassmann and H. Chesbrough (2009). 'Open RandD and open innovation: exploring the phenomenon’, $R \& D$ Management, 39, pp. 311-316.

Escribano, A. Fosfuri, A. and J.A. Tribó (2009). 'Managing external knowledge flows: The moderating role of absorptive capacity’, Research Policy, 38, pp. 96-105

Fosfuri, A. and J. A. Tribó (2008). 'Exploring the antecedents of potential absorptive capacity and its impact on innovation performance', Omega, 36, pp. 173-187.

Gaba, V. and A. Terlaak (2013). 'Decomposing uncertainty and its effects on imitation in firm exit decisions', Organization Science, 24, pp. 1847-1869.

Girma, S. and H. Görg (2007). 'Evaluating the foreign ownership wage premium using a difference-in-differences matching approach', Journal of International Economics, 72, pp. 97-112.

Greenwood, R. and C. Hinings (1996). 'Understanding Radical Organizational Change: Bringing Together the Old and the New Institutionalism', Academy of Management Review, 21, pp. 1022-1054.

Hannan, M. and J. Freeman (1984). 'Structural inertia and organizational change', American Sociological Review, 49, pp.149-164.

Haveman, H. (1993). 'Follow the Leader: Mimetic Isomorphism and Entry into New Markets', Administrative Science Quarterly, 38, pp. 593-627.

He, Z. L. and P. K. Wong (2004). 'Exploration vs. exploitation: An empirical test of the ambidexterity hypothesis', Organization Science, 15, pp. 481-494.

Head, K., T. Mayer and J. Ries (2002). 'Revisiting Oligopolistic Reaction: Are Decisions on Foreign Direct Investments Strategic Complements?', Journal of Economics and Management Strategy, 11, pp. 453-472.

Heckman, J. J. (1979). 'Sample selection bias as a specification error', Econometrica, 47, pp. 153-161.

Hirshleifer, D. and S. H. Teoh (2003) 'Herd behaviour and cascading in capital markets: A review and synthesis’, European Financial Management, 9, pp. 566.

Hunter, G. S. (2013). Out Think: How Innovative Leaders Drive Exceptional Outcomes. Canada: John Wiley \& Sons. 
Hurmelinna-Laukkanen, P. and H. Olander (2014). 'Coping with rivals' absorptive capacity in innovation activities', Technovation, 34, pp. 3-11.

Jacobides, M. G. and S. G. Winter (2012). 'Capabilities: Structure, agency, and evolution’, Organization Science, 23, pp. 1365 - 1381.

Jansen, J. J. P., F. A. J. Van Den Bosch and H. W. Volberda (2005). 'Managing Potential and Realized Absorptive Capacity: How do Organizational Antecedents Matter?’, Academy of Management Journal, 48, pp. 999-1015.

Javorcik, B. S. (2004). 'Does foreign direct investment increase the productivity of domestic firms? In search of spillovers through backward linkages', American Economic Review, 94, pp. 605-627.

Johnson, G., K. Scholes and R. Whittington (2008). Exploring Corporate Strategy (8th Edition). London: Financial Times Prentice Hall.

Johnston, R. and M. Gibbons (1975). 'Characteristics of information usage in technological innovation', IEEE Transactions on Engineering Management, 22, pp. 27-34.

Kafourous, M. I. and P. J. Buckley (2008). 'Under what conditions do firms benefit from the research efforts of other organizations', Research Policy, 37, pp. 225-39.

Kale, D. and S. Little, (2007). 'From imitation to innovation: The evolution of RandD capabilities and learning processes in the Indian pharmaceutical industry', Technology Analysis and Strategic Management, 19, pp. 589-609.

Karlsson, C. and O. Olsson, (1998). 'Product innovation in small and large enterprises', Small Business Economics, 10, pp. 31-46.

Katila, R., and S. Shane (2005). 'When does lack of resources make new firms innovative?', Academy of Management Journal, 48, pp. 814-829

Kerin, R. A., R. R. Varadarajan and R. A. Peterson (1992). 'First-mover advantage: A synthesis, conceptual framework, and research propositions', Journal of Marketing, 56, pp.

Kim, L. (1997). Imitation to Innovation. Mass. Boston: Harvard Business School Press.

King, A. W. and C. P. Zeithaml (2001). 'Competencies and firm performance: Examining the causal ambiguity paradox', Strategic Management Journal, 22, pp.75-99.

Landis, R, and W. Dunlap (2000). 'Moderated multiple regression tests are criterion specific'. Organizational Research Methods, 3, pp. 254-266.

Laursen, K. and A. Salter, (2006). 'Open for innovation: the role of openness in explaining

innovation performance among U.K. manufacturing firms', Strategic Management Journal, 27, pp. 131-150.

Lee, K. and C. Lim (2001). 'Technological regimes, catching-up and leapfrogging: findings from the Korean industries', Research Policy, 30, pp. 459-483.

Leonard-Barton, D. (1992). 'Core capabilities and core rigidities: A paradox in managing new product development’, Strategic Management Journal, 13, pp. 111-125.

Leonidou, L. C. and C. S. Katsikeas (1996). 'The export development process: an integrative review of empirical models', Journal of International Business Studies, 27, pp. 517-551.

Levinthal, D. and J. March (1993). 'The myopia of learning', Strategic Management Journal, 14, pp. 96-112.

Levitt, B. and J. March (1988). 'Organizational learning', American Review of 
Sociology, 14, pp. 319-340.

Li, Y. and W. Vanhaverbeke (2009). 'The relationships between foreign competition, absorptive capacity and pioneering innovation: an empirical investigation in Canada', International Journal of Innovation Management, 13, pp. 105-137.

Lieberman, M. B. and S. Asaba (2006). 'Why do firms imitate each other?', Academy of Management Review, 31, pp. 366-385.

Lieberman, M. B. and D. B. Montgomery (1998). 'First-mover (dis)advantages: Retrospective and link with the resource-based view', Strategic Management Journal, 19, pp.

Lind, J. T. and H. Mehlum (2010). 'With or without U? - The appropriate test for a Ushaped relationship', Oxford Bulletin of Economics and Statistics, 72, pp. 109118.

Liu, X. and T. Buck (2007). 'Innovation performance and channels for international technology spillovers: Evidence from Chinese high-tech industries', Research Policy, 36, pp. 355-366.

Lorenz, J., F. Zilibotti and M. König. 'Distance to frontier, productivity distribution and travelling waves', CEPR's Policy Portal, available at:

http://voxeu.org/article/distance-frontier-productivity-distribution-andtravelling-waves. Lorenz, J., F. Zilibotti and M. König (2015) 'Distance to frontier, productivity distribution and travelling waves', CEPR's Policy Portal, available at: http://voxeu.org/article/distance-frontier-productivitydistribution-and-travelling-waves.

Low, M. B. and E. Abrahamson, (1997). 'Movements, bandwagons, and clones: Industry evolution and the entrepreneurial process', Journal of Business Venturing, 12, pp. 435-457.

Lu, J., X. Liu, and H. Wang (2011). 'Motives for Chinese outward FDI: Firm resources, industry dynamics, and government policies', Management and Organization Review, 7, pp. 223-248.

Luo, Y. and R. L. Tung (2007). 'International expansion of emerging market enterprises: A springboard perspective’, Journal of International Business Studies, 38, pp. 481-498.

Mahmood, I. and C. Rufin (2005). 'Government's Dilemma: The Role of Government in Imitation and Innovation', Academy of Management Review, 30, pp. 338360.

Myers, S. and D. C. Marquis (1969). Successful industrial innovations. Washington, DC: National Science Foundation.

Nickell, S. J. (1996). 'Competition and corporate performance', Journal of Political Economy, 104, pp. 724-746.

Nooteboom, B., W. Van Haverbeke, G. Duysters, V.Gilsing and A. Van den Oord (2007.). 'Optimal cognitive distance and absorptive capacity', Research Policy, 36, pp. 1016-1034.

OECD (2005). 'The Measurement of Scientific and Technological Activities: Guidelines for Collecting and Interpreting Innovation Data: Oslo Manual, Third Edition', prepared by the Working Party of National Experts on Scientific and Technology Indicators, OECD, Paris, para. 163.

Ottke, A. (2015). 'How Camera Companies Are Doing It All Wrong, and How They Could Fix It', Fstoppers, available at: https://fstoppers.com/editorial/howcamera-companies-are-doing-it-all-wrong-and-how-they-could-fix-it-54272.

Penner-Hahn, J. and M. Shaver (2005). 'Does international research and development increase patent output? An analysis of Japanese pharmaceutical firms’, 
Strategic Management Journal, 26, pp. 121-140.

Peteraf, M. A. (1993). 'The cornerstones of competitive advantage: A resource-based view’, Strategic Management Journal, 14, pp. 179-192.

Porter, M. E. (1979). 'The Structure within industries and companies’ performance', Review of Economics and Statistics, 61, pp. 214-227.

Posen, H. E., J. Lee and S. Yi (2013). 'The power of imperfect imitation', Strategic Management Journal, 34, pp. 149-164.

Powell, W. W., K. W. Koput and L. Smith-Doerr (1996). 'Interorganizational collaboration and the locus of innovation: networks of learning in biotechnology', Administrative Science Quarterly, 41, pp. 116-145.

Ramamurti, R. and J. Singh (2009). Indian multinationals: Generic internationalization strategies. In Ramamurti, R. and J. Singh (2009), Emerging Multinationals from Emerging Markets. UK: Cambridge University Press,

Reed, R. \& DeFillippi, R. (1990). Causal ambiguity, barriers to imitation, and sustainable competitive advantage, Academy of Management Journal, 15, pp. 88-102.

Roberts, N. (2015). Absorptive capacity, organizational antecedents, and environmental dynamism', Journal of Business Research, 68, pp. 2426-2433.

Roodman, D. (2007). CMP: conditional mixed process estimator. Statistical software components S456882, Boston: Boston College Department of Economics.

Ross, J. and D. Sharapov (2015). 'When the leader follows: avoiding dethronement through imitation', Academy of Management Journal, 58, pp. 658-679.

Rothaermel, F. T. (2001). 'Incumbent's advantage through exploiting complementary assets via interfirm cooperation', Strategic Management Journal, 22, pp. 687699.

Rothaermel, F. T. and M. T. Alexandre (2009). 'Ambidexterity in Technology Sourcing: The Moderating Role of Absorptive Capacity’, Organization Science, 20, pp. 759-780.

Rothaermel, F. T. and A. M. Hess (2007). 'Building dynamic capabilities: Innovation driven by individual-, firm-, and network-level effects', Organization Science, 18, pp. 898 - 921.

Salomon, R. and Z. Wu (2012) 'Institutional distance and local isomorphism strategy', Journal of International Business Studies, 43, pp. 343-367.

Sasabuchi, S. (1980). 'A test of a multivariate normal mean with composite hypotheses determined by linear inequalities’, Biometrika, 67, pp. 429-439.

Schumpeter, J. A. (1950). Capitalism, socialism, and democracy (3rd ed.). New York: Harper.

Semadeni, M. and B. S. Anderson (2010). 'The follower's dilemma: Innovation and imitation in the professional services industry', Academy of Management Journal, 53, pp. 1175-1193

Shankar, V., G. S. Carpenter and L. Krishnamurthi (1998). 'Late mover advantage: How innovative late entrants outsell pioneers', Journal of Marketing Research, 35, pp.

Shenkar, O. (2010). 'Copycats: how smart companies use imitation to gain a strategic edge', Strategic Direction, 26, pp. 3-5.

Simon, H. A. (1969). Sciences of the artificial. Cambridge, MA: M.I.T. Press.

Stock, G. N., N. P. Greis and W. A. Fischer (2001). 'Absorptive capacity and new product development', The Journal of High Technology Management Research, 12, pp.77-91. 
Stones, R. (2001). UK Innovation Survey 2001. London: Department of Trade and Industry.

Strang, D. and M. W. Macy (2001). 'In Search of Excellence: Fads, Success Stories, and Adaptive Emulation', American Journal of Sociology, 107, pp. 147-182.

Strang, D. and M.C., Still. (2006). Does ambiguity promote imitation or hinder it? An empirical study of benchmarking teams. European Management Review, 3, pp. 101-112.

Szulanski, G. (1996). 'Exploring internal stickiness: Impediments to the transfer of best practice within the firm', Strategic Management Journal, 17, pp. 27-43.

Sull, D. (1999). 'Why good companies go bad', Harvard Business Review, 77, pp. $42-$ 56.

Tang, J. (2006). 'Competition and Innovation Behaviour', Research Policy, 35, 6882.

Terlaak, A. and A. A. King (2007). 'Follow the small? Information revealing adoption bandwagons when observers expect larger firms to benefit more from adoption', Strategic Management Journal, 28, pp. 1167-1185.

Un, C. A., A. Cuervo-Cazurra and K. Asakawa (2010). 'R\&D Collaborations and Product Innovation', Journal of Product Innovation Management, 27, pp. 673-689.

Un, C. A. (2011). 'The advantage of foreignness in innovation', Strategic Management Journal, 32, pp. 1232-1242.

Van de Ven, A. (1986). 'Central problems in the management of innovation', Management Science, 32, pp. 590-607.

von Hippel, E. (1988). The Sources of Innovation. New York, US: Oxford University Press.

Weick, K. E. and F. Westley (1996). 'Organizational learning: Affirming an oxymoron', In Clegg, S. R., C. Hardy and W. R. Nord (Eds.), Handbook of organization studies:440-458. Thousand Oaks, CA: Sage.

Xia, J., Ma, X., J. Lu and D. W. Liu (2014). 'Outward foreign direct investment by emerging market firms. A resource dependence logic’, Strategic Management Journal, 50(7), pp. 1322-1346.

$\mathrm{Wu}, \mathrm{Z}$ and R. Salomon (2016) 'Does imitation reduce the liability of foreignness? Linking distance, isomorphism, and performance', Strategic Management Journal, available at http://onlinelibrary.wiley.com/doi/10.1002/smj.2462/full.

Zahra, S. A. and G. George (2002). 'Absorptive capacity: a review, reconceptualization, and extension', Academy of Management Review, 27, pp. 185-203.

Zahra, S. A. and J. C. Hayton (2008). 'The effect of international venturing on firm performance: The moderating influence of absorptive capacity', Journal of Business Venturing, 23, pp. 195-220.

Zhang, S. and A. B. Markman (1998). 'Overcoming the early entrant advantage: The role of alignable and nonalignable difference', Journal of Marketing Research, 35, pp.

Zhang, Y., Y. Li and H. Li, (2014). 'FDI spillovers over time in an emerging market: The roles of entry tenure and barriers to imitation', Academy of Management Journal, 57, pp. 698-722. 